Louisiana State University

LSU Digital Commons

Faculty Publications

Department of Biological Sciences

7-1-2006

\title{
Biocatalytic and antimetastatic studies of the marine cembranoids sarcophine and 2-epi-16-deoxysarcophine
}

\author{
Swapnali S. Sawant \\ University of Louisiana at Monroe \\ Diaa T.A. Youssef \\ Suez Canal University \\ Jane Reiland \\ School of Veterinary Medicine \\ Melissa Ferniz \\ School of Veterinary Medicine \\ Dario Marchetti \\ School of Veterinary Medicine
}

See next page for additional authors

Follow this and additional works at: https://digitalcommons.Isu.edu/biosci_pubs

\section{Recommended Citation}

Sawant, S., Youssef, D., Reiland, J., Ferniz, M., Marchetti, D., \& El Sayed, K. (2006). Biocatalytic and antimetastatic studies of the marine cembranoids sarcophine and 2-epi-16-deoxysarcophine. Journal of Natural Products, 69 (7), 1010-1013. https://doi.org/10.1021/np050527v

This Article is brought to you for free and open access by the Department of Biological Sciences at LSU Digital Commons. It has been accepted for inclusion in Faculty Publications by an authorized administrator of LSU Digital Commons. For more information, please contact ir@lsu.edu. 
Authors

Swapnali S. Sawant, Diaa T.A. Youssef, Jane Reiland, Melissa Ferniz, Dario Marchetti, and Khalid A. El Sayed 


\title{
Biocatalytic and Antimetastatic Studies of the Marine Cembranoids Sarcophine and 2-epi-16-Deoxysarcophine
}

\author{
Swapnali S. Sawant, ${ }^{\dagger}$ Diaa T. A. Youssef,${ }^{\ddagger}$ Jane Reiland, ${ }^{\S}$ Melissa Ferniz,${ }^{\S}$ Dario Marchetti, ${ }^{\S}$ and Khalid A. El Sayed ${ }^{*} \dagger$ \\ Department of Basic Pharmaceutical Sciences, College of Pharmacy, University of Louisiana at Monroe, 700 University Avenue, \\ Monroe, Louisiana 71209, Department of Pharmacognosy, Faculty of Pharmacy, Suez Canal University, Ismailia 41522, Egypt, and \\ Department of Comparative Biomedical Sciences, School of Veterinary Medicine, Louisiana State University-Baton Rouge, \\ Baton Rouge, Louisiana 70803
}

Received December 13, 2005

\begin{abstract}
The soft coral Sarcophyton glaucum is a rich resource of several bioactive cembranoids. Sarcophytol A (1) and sarcophine (2) are cembranoid diterpenes reported from this soft coral and extensively investigated for their cancer chemopreventive properties. This study aimed at investigating the antimetastatic potential of the major cembranoids, sarcophine (2) and 2-epi-16-deoxysarcophine (3), from the Red Sea soft coral S. glaucum. Biocatalytic transformation of $\mathbf{3}$ using Rhizopus stolonifer ATCC 6227a and Absidia spinosa ATCC 6648 afforded four new metabolites, 5-7 and 9, along with the known $9 \alpha$-hydroxysarcophine (8). Sarcophine, 2-epi-16-deoxysarcophine, and metabolites 5-9 revealed significant antimetastatic activity against the highly metastatic mouse melanoma cell line (B16B15b). Cembranoids demonstrate a great potential for further development as antimetastatic agents.
\end{abstract}

Soft corals are marine invertebrates possessing a vast range of terpenoid metabolites. ${ }^{1}$ These terpenes, mainly cembranoids, represent the animal's main chemical defense tools against its natural predators. ${ }^{2,3}$ Cembranoids exhibit a wide range of biological activities including neuroprotective, antimicrobial, and antitumor properties. ${ }^{2,3}$ The soft coral Sarcophyton is one of the most abundant coral reef animals with a high cembranoid content. ${ }^{4}$ The cancer chemopreventive properties of the two major Sarcophyton cembranoids, sarcophytol A (1) and sarcophine (2), are well documented. ${ }^{5-8}$ Several attempts to optimize the anticancer potential of sarcophine have previously been reported..$^{6-8}$ However, no similar studies were reported for other major cembranoids from this soft coral. Biocatalysis demonstrates many advantages including high regio-, stereo-, and chemoselectivity and the ability to generate novel and diverse derivatives. ${ }^{9}$ Biocatalysis was successfully used to enhance the anticancer potential of sarcophine. ${ }^{6}$ The related olibanum cembranoid incensole (4) was patented for its antiangiogenic activity. ${ }^{10}$ Based on correlations between angiogenesis and cancer metastasis as well as the reported chemopreventive activities of sarcophytol A and sarcophine, cembranoids could possess antimetastatic properties.

Hence, this study aims at (1) isolation of major cembranoids from Sarcophyton glaucum; (2) optimization of the major cembranoid 2-epi-16-deoxysarcophine (3) using biocatalysis to generate structurally diverse analogues; and (3) evaluating the ability of cembranoids to inhibit the migration of the highly metastatic melanoma cells (B16B15b).

\section{Results and Discussion}

Reinvestigation of the Red Sea soft coral $S$. glaucum led to the isolation of two known cembranoids, sarcophine (2) and 2-epi-16deoxysarcophine (3), in high yields. The identification of $\mathbf{2}$ and $\mathbf{3}$ was based on extensive analysis of their NMR data and comparison with the literature. ${ }^{11-13}$ There have been discrepancies in the nomenclature of $2 S, 7 S, 8 S$-16-deoxysarcophine and $2 R, 7 S, 8 S$-16deoxysarcophine. Irrespective of the C-2 configuration, this com-

* To whom correspondence should be addressed. Tel: 318-342-1725. Fax: 318-342-1737. E-mail: elsayed@ulm.edu.

$\dagger$ University of Louisiana at Monroe.

$\doteqdot$ Suez Canal University.

$\S$ Louisiana State University.

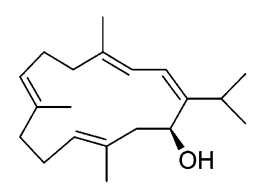

1 Sarcophytol A

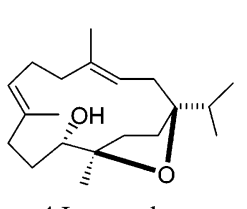

4 Incensole

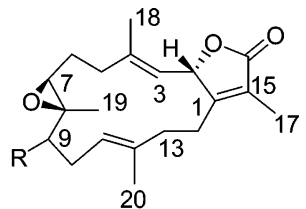

2 Sarcophine, $\mathrm{R}=\mathrm{H}$

8, $\mathrm{R}=\alpha-\mathrm{OH}$

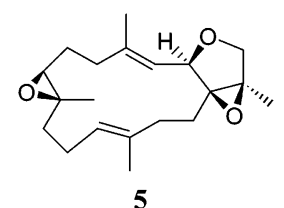<smiles></smiles>

$\begin{array}{llll} & \mathrm{R}_{1} & \mathrm{R}_{2} & \mathrm{R}_{3} \\ \mathbf{3} & \mathrm{H} & \mathrm{H} & \mathrm{H} \\ \mathbf{6} & \alpha-\mathrm{OH} & \mathrm{H} & \mathrm{H} \\ \mathbf{7} & \mathrm{H} & \beta-\mathrm{OH} & \mathrm{H} \\ \mathbf{9} & \mathrm{H} & \mathrm{H} & \beta-\mathrm{OH}\end{array}$

pound has been referred to as sarcophytoxide, 16-deoxosarcophine, and 16-deoxysarcophine. ${ }^{13-15}$ The name 16-deoxysarcophine should be used to describe $2 S, 7 S, 8 S$-16-deoxysarcophine in order to unify the literature nomenclature and to correlate its structure with sarcophine (2), whose absolute configuration is well established as $2 S, 7 S, 8 S$ by X-ray crystallography and modified Mosher's method. ${ }^{11,16} 2 R, 7 S, 8 S$-16-Deoxysarcophine (3) should then be named 2-epi-16-deoxysarcophine, to clearly denote the opposite C-2 configuration compared to sarcophine.

The success of the previous bioconversion study of sarcophine that led to metabolites with enhanced anticancer activity encouraged a similar study for 3 . $^{6}$ Thirty growing cultures were screened for their ability to bioconvert 2-epi-16-deoxysarcophine. Of these, Rhizopus stolonifer ATCC 6227a and Absidia spinosa ATCC 6648 were selected for the scale-up fermentation based on the diversity of the generated metabolites. 
Table 1. ${ }^{13} \mathrm{C}$ and ${ }^{1} \mathrm{H}$ NMR Data of Compounds $5-7^{a}$

\begin{tabular}{|c|c|c|c|c|c|c|}
\hline \multirow[b]{2}{*}{ position } & \multicolumn{2}{|r|}{$\mathbf{5}^{a}$} & \multicolumn{2}{|r|}{$6^{a}$} & \multicolumn{2}{|c|}{$7^{a}$} \\
\hline & $\delta_{\mathrm{C}}$ & $\delta_{\mathrm{H}}$ & $\delta_{\mathrm{C}}$ & $\delta_{\mathrm{H}}$ & $\delta_{\mathrm{C}}$ & $\delta_{\mathrm{H}}$ \\
\hline 1 & $72.4, \mathrm{C}$ & & 133.6, C & & $133.5, \mathrm{C}$ & \\
\hline 2 & $78.2, \mathrm{CH}$ & $4.82, \mathrm{~d}(10.9)$ & $85.3, \mathrm{CH}$ & $5.40, \mathrm{~m}$ & $85.3, \mathrm{CH}$ & $5.37, \mathrm{~m}$ \\
\hline 3 & $122.5, \mathrm{CH}$ & $5.27, \mathrm{~d}(9.8)$ & $125.5, \mathrm{CH}$ & $5.29, \mathrm{~d}(9.5)$ & $124.9, \mathrm{CH}$ & $5.17, \mathrm{~d}(9.6)$ \\
\hline 4 & $142.5, \mathrm{C}$ & & $140.2, \mathrm{C}$ & & $139.8, \mathrm{C}$ & \\
\hline 5 & $35.5, \mathrm{CH}_{2}$ & $2.34, \mathrm{~m}, 2.23, \mathrm{~m}$ & $34.7, \mathrm{CH}_{2}$ & $2.30, \mathrm{~m}, 2.25, \mathrm{~m}$ & $35.0, \mathrm{CH}_{2}$ & $2.29, \mathrm{~m}, 2.24, \mathrm{~m}$ \\
\hline 6 & $29.5, \mathrm{CH}_{2}$ & $1.87, \mathrm{~m}, 1.66, \mathrm{~m}$ & 27.0, $\mathrm{CH}_{2}$ & $1.87, \mathrm{~m}, 1.71, \mathrm{~m}$ & 26.4, $\mathrm{CH}_{2}$ & $2.10, \mathrm{~m}, 1.77, \mathrm{~m}$ \\
\hline 7 & $62.4, \mathrm{CH}$ & $2.67, \mathrm{t}(5.5)$ & $62.1, \mathrm{CH}$ & $2.68, \mathrm{t}(5.5)$ & $61.6, \mathrm{CH}$ & $2.68, \mathrm{t}(5.7)$ \\
\hline 8 & $60.0, \mathrm{C}$ & & $63.4, \mathrm{C}$ & & $59.4, \mathrm{C}$ & \\
\hline 9 & $38.5, \mathrm{CH}$ & $1.62, \mathrm{~m}, 1.23, \mathrm{~m}$ & $78.8, \mathrm{CH}$ & $2.98, \mathrm{dd}(11.7,4.7)$ & $45.4, \mathrm{CH}_{2}$ & $2.22, \mathrm{~m}, 1.50, \mathrm{~m}$ \\
\hline 10 & $23.2, \mathrm{CH}_{2}$ & $2.20, \mathrm{~m}, 2.08, \mathrm{~m}$ & $31.5, \mathrm{CH}_{2}$ & $2.45, \mathrm{~m}, 2.05, \mathrm{~m}$ & $65.0, \mathrm{CH}$ & $4.50, \mathrm{~m}$ \\
\hline 11 & $123.0, \mathrm{CH}$ & $5.08, \mathrm{t}(7.0)$ & $118.2, \mathrm{CH}$ & $4.88, \mathrm{t}(9.2)$ & $127.0, \mathrm{CH}$ & $5.18, \mathrm{~d}(7.3)$ \\
\hline 12 & $135.2, \mathrm{C}$ & & $138.9, \mathrm{C}$ & & $138.5, \mathrm{C}$ & \\
\hline 13 & $34.5, \mathrm{CH}_{2}$ & $1.95, \mathrm{~m}, 1.89, \mathrm{~m}$ & $39.2, \mathrm{CH}_{2}$ & $2.38, \mathrm{~m}, 2.35, \mathrm{~m}$ & $38.4, \mathrm{CH}_{2}$ & $2.10, \mathrm{~m}, 1.60, \mathrm{~m}$ \\
\hline 14 & $25.9, \mathrm{CH}_{2}$ & $1.60, \mathrm{~m}$ & $28.9, \mathrm{CH}_{2}$ & $1.90, \mathrm{~m}, 1.52, \mathrm{~m}$ & $23.0, \mathrm{CH}_{2}$ & $2.40, \mathrm{~m}, 2.30, \mathrm{~m}$ \\
\hline 15 & $67.8, \mathrm{C}$ & & $128.2, \mathrm{C}$ & & $128.5, \mathrm{C}$ & \\
\hline 16 & $70.1, \mathrm{CH}_{2}$ & $3.86, d(9.9), 3.75, \mathrm{~d}(9.9)$ & $78.5, \mathrm{CH}_{2}$ & $4.50, \mathrm{dq}(12.0,5.5), 4.47, \mathrm{dq}(12.0,5.5)$ & $78.5, \mathrm{CH}_{2}$ & $4.45, \mathrm{~m}, 4.41, \mathrm{~m}$ \\
\hline 17 & $12.8, \mathrm{CH}_{3}$ & $1.45,3 \mathrm{H}, \mathrm{s}$ & $10.5, \mathrm{CH}_{3}$ & $1.65,3 \mathrm{H}, \mathrm{brs}$ & $10.6, \mathrm{CH}_{3}$ & $1.67,3 \mathrm{H}, \mathrm{brs}$ \\
\hline 18 & $18.6, \mathrm{CH}_{3}$ & $1.90,3 \mathrm{H}, \mathrm{s}$ & $17.8, \mathrm{CH}_{3}$ & $1.85,3 \mathrm{H}, \mathrm{s}$ & 17.6, $\mathrm{CH}_{3}$ & $1.78,3 \mathrm{H}, \mathrm{s}$ \\
\hline 19 & $16.4, \mathrm{CH}_{3}$ & $1.20,3 \mathrm{H}, \mathrm{s}$ & $10.0, \mathrm{CH}_{3}$ & $1.26,3 \mathrm{H}, \mathrm{s}$ & $19.5, \mathrm{CH}_{3}$ & $1.38,3 \mathrm{H}, \mathrm{s}$ \\
\hline 20 & $15.7, \mathrm{CH}_{3}$ & $1.62,3 \mathrm{H}, \mathrm{s}$ & $15.5, \mathrm{CH}_{3}$ & $1.62,3 \mathrm{H}, \mathrm{s}$ & $16.2, \mathrm{CH}_{3}$ & $1.62,3 \mathrm{H}, \mathrm{s}$ \\
\hline
\end{tabular}

${ }^{a}$ In $\mathrm{CDCl}_{3}, 400 \mathrm{MHz}$ for ${ }^{1} \mathrm{H}$ and ${ }^{13} \mathrm{C}$ NMR. Coupling constants $(J)$ are in $\mathrm{Hz}$.

Fourteen-day fermentation of $\mathbf{3}$ with $R$. stolonifer afforded four more polar metabolites, 5-8. The HRMS data of compound $\mathbf{5}$ suggested a molecular formula of $\mathrm{C}_{20} \mathrm{H}_{30} \mathrm{O}_{3}$ and six degrees of unsaturation. The ${ }^{1} \mathrm{H}$ and ${ }^{13} \mathrm{C}$ NMR data (Table 1) suggested 1,15 epoxidation and the presence of two macrocyclic double bonds. The quaternary oxygenated carbons at $\delta 72.4$ and 67.8 were assigned to $\mathrm{C}-1$ and $\mathrm{C}-15$, respectively. This was aided by their ${ }^{3} J$ - and ${ }^{2} J$-HMBC correlations with the $\mathrm{H}_{3}-17$ methyl singlet. The upfield shift of $\mathrm{H}_{3}-17(\delta 1.45)$, compared with $\mathrm{H}_{3}-17$ in the parent compound $\mathbf{3}$, indicated the replacement of $\Delta^{1,15}$ in $\mathbf{3}$ with an epoxy functionality in $\mathbf{5}$. This was further confirmed by the ${ }^{2} J$ - and ${ }^{3} J$ HMBC correlations of the H-2 doublet ( $\delta 4.82)$ with C-1 and C-15, respectively. The 14-membered macrocycle of $\mathbf{3}$ is identical to that of sarcophine (2), which has restricted mobility on the basis of $\mathrm{X}$-ray crystallography. ${ }^{11}$ The unique nature of sarcophine's 14membered ring macrocycle was previously reported. ${ }^{11}$ The existence of the segment $\mathrm{C}-7-\mathrm{C}-11$ in a half-chair conformer, as proved by X-ray crystallography and NOE difference data, restricts the mobility freedom in the entire macrocycle.,11 This was further supported by the high $J$ and dihedral angle values between $\mathrm{H}-2$ and $\mathrm{H}-3$ in sarcophine $\left(10.5 \mathrm{~Hz}\right.$ and $\left.\sim 160^{\circ}\right)$ and the paramagnetic deshielding of the $\mathrm{C}-18$ methyl functionality by the $\mathrm{C}-2$ oxygen. ${ }^{6,11}$ This is true whenever the epoxy group is intact; hence, the relative stereochemistry of the biocatalytic products of $\mathbf{3}$ was assigned on the basis of NOESY correlations. The presence of the C-7/C-8 epoxide forces the functional groups on C-7 and C-8 to be eclipsed and the methylene groups $\mathrm{C}-6$ and $\mathrm{C}-9$ to be in an anti-configuration around the $\mathrm{C}-7-\mathrm{C}-8$ bond. ${ }^{6,11} \mathrm{NOESY}$ is widely employed for the assignment of relative stereochemistry of structurally diverse cembrane diterpenes isolated from soft corals. ${ }^{17,18}$ The $\alpha$-oriented $\mathrm{H}_{3}-19$ methyl singlet $(\delta$ 1.20) in 5 showed a strong NOESY correlation with $\mathrm{H}_{3}-17$, indicating a similar stereo-orientation. Thus, the $\mathrm{C}-1-\mathrm{C}-15$ epoxide group of $\mathbf{5}$ should be $\beta$-oriented.

The HRMS and NMR data of $\mathbf{6}$ (Table 1) suggested a monohydroxylated analogue of $\mathbf{3}$. The newly oxygenated doublet of doublets $(\delta 2.98, J=11.7$ and $4.7 \mathrm{~Hz}$ ) was assigned to $\mathrm{H}-9$. The location of the new C-9 hydroxy group was based on HMBC data. The methyl singlet at $\mathrm{H}_{3}-19$ showed a ${ }^{3} J$-HMBC correlation with the new oxygenated methine at $\delta 78.8$, which was then assigned to C-9. This assignment was also confirmed by the ${ }^{3} J-H M B C$ correlations of $\mathrm{H}-7$ ( $\delta$ 2.68) with C-9. The stereochemistry assignment of C-9 was based on comparison of the ${ }^{13} \mathrm{C}$ NMR chemical shift and coupling constants with those of the previously reported $9 \alpha$-hydroxysarcophine. ${ }^{6}$ The reported chemical shift value of C-9 in $9 \alpha$-hydroxysarcophine is at $\delta 78.6$ and $\mathrm{H}-9$ resonates at $\delta 2.95(\mathrm{dd}, J=11.8,4.1 \mathrm{~Hz}){ }^{6}$ By contrast, the reported C-9 chemical shift value in $9 \beta$-hydroxysarcophine is at $\delta 70.7$ and $\mathrm{H}-9$ resonates at $\delta 3.92(\mathrm{dd}, J=4.8,2.1 \mathrm{~Hz}){ }^{6}$

The HRMS and NMR data of 7 (Table 1) indicated monohydroxylation. The olefinic proton doublet at H-11 $(\delta$ 5.18) showed a COSY correlation with the new oxygenated proton multiplet at $\mathrm{H}-10\left(\delta\right.$ 4.50). Proton $\mathrm{H}-11$ also showed a ${ }^{2} J$-HMBC correlation with $\mathrm{C}-10(\delta 65.0)$. The $\alpha$-orientation of $\mathrm{H}-10$ was based on its NOESY correlation with the $\alpha$-oriented $\mathrm{H}_{3}-19(\delta$ 1.38).

The HRMS and NMR data (Table 2) of 8 suggested the molecular formula $\mathrm{C}_{20} \mathrm{H}_{28} \mathrm{O}_{4}$, monohydroxylation, and an $\alpha, \beta$ unsaturated lactone system. The most downfield carbon signals at $\delta 174.9(\mathrm{C}-16)$ and $162.5(\mathrm{C}-1)$ and the downfield shifted $\mathrm{H}-2$ at $\delta 5.44(\mathrm{dq}, J=9.7,1.8)$ indicated a sarcophine-like $\alpha, \beta$-unsaturated lactone. The hydroxylated proton at $\mathrm{H}-9(\delta 2.96$, dd, $J=11.7$, 4.7) showed a close resemblance to that of $9 \alpha$-hydroxy-2-epi-16deoxysarcophine (6). Compound $\mathbf{8}$ was identical to the previously reported sarcophine bioconversion product $9 \alpha$-hydroxysarcophine. ${ }^{6}$ Comparison of the TLC and ${ }^{1} \mathrm{H}$ NMR of the total fermentation mixture of 3 with $R$. stolonifer versus substrate control, 2-epi-16deoxysarcophine in blank compound medium $\alpha$, indicated that $\mathbf{8}$ is a true microbial metabolite and not an artifact formed by air oxidation of $\mathbf{3}$ to sarcophine. Faulkner and co-workers previously suggested a possible C-2 epimerization after oxidation of C-16. ${ }^{14}$ The present data provide a strong support of this prediction.

Bioconversion of $\mathbf{3}$ using A. spinosa ATCC 6648 predominantly yielded compound 9. The HRMS and NMR data (Table 2) of 9 suggested a monhydroxylated analogue. The oxygenated proton multiplet at H-14 $(\delta 4.69)$ showed a COSY correlation with the methylene protons at $\mathrm{H}_{2}-13(\delta$ 2.45). The oxygenated proton multiplet at $\mathrm{H}-2(\delta 5.70)$ showed a ${ }^{3} \mathrm{~J}$-HMBC correlation with $\mathrm{C}-14$ $(\delta$ 66.2), confirming the hydroxylation at this position. The $\alpha$-oriented H-2 showed a NOESY correlation with H-16a $(\delta 4.60)$, which in turn showed a NOESY correlation with H-14, suggesting a similar $\alpha$-orientation.

Antimigratory Activity. Migration and proliferation are events underlying cancer metastasis. The antimigratory potential of three different concentrations of compounds 2-9 was evaluated using wound-healing assays. ${ }^{19-21}$ The highly metastatic mouse melanoma cell line (B16B15b) was used. ${ }^{19-21}$ All cembranoids showed a dosedependent increase in the inhibition of migration (Figures 1 and 2). Sarcophine (2) was the most potent of all tested compounds. The $9 \alpha$-hydroxy derivative (6) showed an improved activity 
Table 2. ${ }^{13} \mathrm{C}$ and ${ }^{1} \mathrm{H}$ NMR Data of Compounds 8 and $\mathbf{9}^{a}$

\begin{tabular}{|c|c|c|c|c|}
\hline \multirow[b]{2}{*}{ position } & \multicolumn{2}{|c|}{$\mathbf{8}^{a}$} & \multicolumn{2}{|r|}{$\mathbf{9}^{a}$} \\
\hline & $\delta_{\mathrm{C}}$ & $\delta_{\mathrm{H}}$ & $\delta_{\mathrm{C}}$ & $\delta_{\mathrm{H}}$ \\
\hline 1 & $162.5, \mathrm{C}$ & & 137.1, C & \\
\hline 2 & $79.7, \mathrm{CH}$ & $5.44, \mathrm{dq}(9.7,1.8)$ & $84.1, \mathrm{CH}$ & $5.70, \mathrm{~m}$ \\
\hline 3 & $119.3, \mathrm{CH}$ & $5.04, \mathrm{~d}(9.7)$ & $125.9, \mathrm{CH}$ & $5.29, \mathrm{~d}(9.5)$ \\
\hline 4 & 145.3, C & & $138.5, \mathrm{C}$ & \\
\hline 5 & 34.6, $\mathrm{CH}_{2}$ & $2.41, \mathrm{~m}, 2.37, \mathrm{~m}$ & $37.4, \mathrm{CH}_{2}$ & $2.35, \mathrm{~m}, 2.28, \mathrm{~m}$ \\
\hline 6 & 26.6, $\mathrm{CH}_{2}$ & $1.80, \mathrm{~m}, 1.62, \mathrm{~m}$ & $25.6, \mathrm{CH}_{2}$ & $1.75, \mathrm{~m}, 1.65, \mathrm{~m}$ \\
\hline 7 & $61.2, \mathrm{CH}$ & $2.63, \mathrm{t}(5.5)$ & $61.0, \mathrm{CH}$ & $2.63, \mathrm{t}(5.5)$ \\
\hline 8 & $63.4, \mathrm{C}$ & & $60.8, \mathrm{C}$ & \\
\hline 9 & $78.6, \mathrm{CH}$ & $2.96, \mathrm{dd}(11.7,4.7)$ & $35.9, \mathrm{CH}_{2}$ & $2.08, \mathrm{~m}, 1.95, \mathrm{~m}$ \\
\hline 10 & $31.5, \mathrm{CH}_{2}$ & $2.48, \mathrm{~m}, 2.08, \mathrm{~m}$ & $23.4, \mathrm{CH}_{2}$ & $1.54,2 \mathrm{H}, \mathrm{m}$ \\
\hline 11 & $119.2, \mathrm{CH}$ & $4.96, \mathrm{dd}(10.3,6.6)$ & $128.0, \mathrm{CH}$ & $5.15, \mathrm{t}(7.0)$ \\
\hline 12 & 137.6, C & & $128.3, \mathrm{C}$ & \\
\hline 13 & $37.6, \mathrm{CH}_{2}$ & $2.30, \mathrm{~m}, 1.82, \mathrm{~m}$ & $45.8, \mathrm{CH}_{2}$ & $2.45,2 \mathrm{H}, \mathrm{m}$ \\
\hline 14 & $28.9, \mathrm{CH}_{2}$ & $2.84, \mathrm{~m}, 1.95, \mathrm{~m}$ & $66.2, \mathrm{CH}$ & $4.69, \mathrm{~m}$ \\
\hline 15 & $123.2, \mathrm{C}$ & & $130.9, \mathrm{C}$ & \\
\hline 16 & 174.9, C & & $78.5, \mathrm{CH}_{2}$ & $4.60, \mathrm{dq}(12.1,5.5), 4.42, \mathrm{~d}(12.1)$ \\
\hline 17 & $9.1, \mathrm{CH}_{3}$ & $1.84,3 \mathrm{H}$, brs & $10.7, \mathrm{CH}_{3}$ & $1.64,3 \mathrm{H}, \mathrm{s}$ \\
\hline 18 & $18.3, \mathrm{CH}_{3}$ & $1.93,3 \mathrm{H}, \mathrm{s}$ & $15.9, \mathrm{CH}_{3}$ & $1.78,3 \mathrm{H}, \mathrm{s}$ \\
\hline 19 & $9.7, \mathrm{CH}_{3}$ & $1.29,3 \mathrm{H}, \mathrm{s}$ & $18.1, \mathrm{CH}_{3}$ & $1.23,3 \mathrm{H}, \mathrm{s}$ \\
\hline 20 & $16.9, \mathrm{CH}_{3}$ & $1.64,3 \mathrm{H}, \mathrm{s}$ & $16.8, \mathrm{CH}_{3}$ & $1.66,3 \mathrm{H}, \mathrm{s}$ \\
\hline
\end{tabular}

${ }^{a}$ In $\mathrm{CDCl}_{3}, 400 \mathrm{MHz}$ for ${ }^{1} \mathrm{H}$ and ${ }^{13} \mathrm{C}$ NMR. Coupling constants $(J)$ are in $\mathrm{Hz}$.
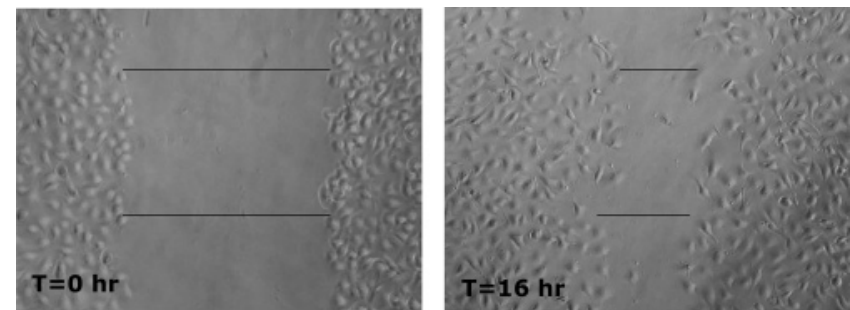

Figure 1. Relative gap closure in the presence of $10 \mu \mathrm{M}$ $9 \alpha$-hydroxy-2-epi-16-deoxysarcophine (6) at 0 and $16 \mathrm{~h}$ after wounding of B16B15b mouse melanoma cells.

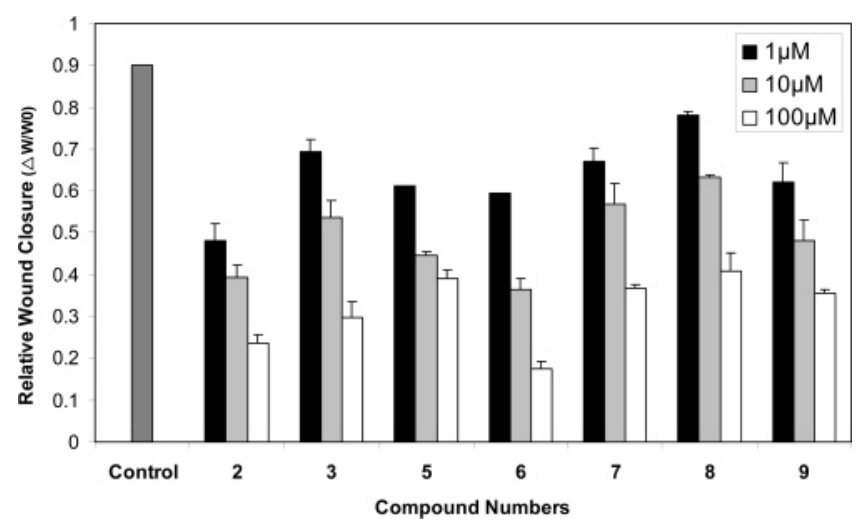

Figure 2. Effect of different concentrations of sarcophine, 2-epi16-deoxysarcophine, and cembranoid derivatives on the migration of highly metastatic B16B15b mouse melanoma cells.

compared to its parent compound 2-epi-16-deoxysarcophine (3). Cembranoids $(1$ and $10 \mu \mathrm{M})$ did not show a significant effect on cell proliferation, indicating that cembranoids' tumor cell migration inhibition was not attributed to cytotoxicity but due to the inhibition of migratory pathways

Conclusions. Biocatalysis of 2-epi-16-deoxysarcophine afforded four new and one known metabolites. The transformation of $\mathbf{3}$ to $9 \alpha$-hydroxysarcophine provided evidence for Faulkner's previously proposed hypothesis of possible C-2 epimerization after C-16 oxidation of deoxysarcophine. The antimigratory effect of cembranoids is reported for the first time. C-16-oxygenated cembranoids show better antimigratory activity compared to 16 -deoxycembranoids.

\section{Experimental Section}

General Experimental Procedures. Optical rotations were measured on a Rudolph Research Analytical Autopol III polarimeter. IR spectra were recorded on a Nicolet Impact 400D FTIR spectrophotometer. The ${ }^{1} \mathrm{H}$ and ${ }^{13} \mathrm{C}$ NMR spectra were recorded in $\mathrm{CDCl}_{3}$, on a JEOL Eclipse NMR spectrometer operating at $400 \mathrm{MHz}$ for proton and $100 \mathrm{MHz}$ for carbon. The HRESITOF experiments were conducted at the University of Michigan on a Micromass LCT spectrometer and the University of Minnesota on a Bruker BioTOF II spectrometer. TLC analyses were carried out on precoated silica gel $\mathrm{G}_{254} 500 \mu \mathrm{m}$, using the developing systems $n$-hexane/EtOAc (3:2) and $\mathrm{CHCl}_{3} / \mathrm{MeOH}$ (4: 1). For medium-pressure liquid column chromatography (MPLC), $\mathrm{Si}$ gel $<63 \mu \mathrm{m}$ particle size mesh was used.

Materials. The soft coral S. glaucum was collected by scuba in June 2003 from Hurghada, at the Egyptian Red Sea coast. A voucher specimen (03RS24) was deposited in the Department of Basic Pharmaceutical Sciences, College of Pharmacy, University of Louisiana at Monroe. The frozen soft coral $(680 \mathrm{~g})$ was extracted four times with 2-propanol in a percolator at room temperature. The extract ( $86 \mathrm{~g}$ ) was then concentrated under vacuum and chromatographed on silica gel using $n$-hexane/EtOAc to yield $1.5 \mathrm{~g}$ of sarcophine (2), which was further recrystallized from EtOAc. Further chromatographic separation of the extract afforded the less polar 2-epi-16-deoxysarcophine (3, 4.1 g, $R_{f} 0.50 n$-hexane/EtOAc, 7:3).

Biocatalysis of 2-epi-16-Deoxysarcophine. Biocatalysis studies were conducted as described elsewhere. ${ }^{6}$ Thirty growing ATCC microbial cultures were used for screening of $\mathbf{3}$. These organisms were similar to those previously reported in addition to Absidia spinosa ATCC 6648, Cunninghamella homothallica ATCC 16161, Cunninghamella verticillata ATCC 8986, Kluyveromyces africanus ATCC 22294, Lipomyces starkeyi ATCC 58680, Phanerochaete chrysosporium ATCC 24725, Rhizopus niveus ATCC 200757, Rhizopus oligosporus ATCC 76011, Saccharomyces pastorianus ATCC 2366, and Streptomyces malaysienesis BAA-13. ${ }^{6}$

R. stolonifer ATCC 6227a and A. spinosa ATCC 6648 were selected for scale-up. Each of these organisms was inoculated in $101 \mathrm{~L}$ flasks containing compound medium $\alpha .^{6}$ After $72 \mathrm{~h}, 500 \mathrm{mg}$ of $\mathbf{3}$ was dissolved in $3 \mathrm{~mL}$ of ethanol and evenly distributed in all flasks (250 $\mathrm{mg}$ per organism, $25 \mathrm{mg} / \mathrm{flask}$ ). After 14 days, the growth medium was filtered and extracted with EtOAc $(4 \times 1000 \mathrm{~mL})$. The EtOAc layer was then concentrated under vaccuum to give 350 and $415 \mathrm{~g}$ of crude extracts, respectively. Fermentation extract of A. spinosa was subjected to silica gel 60 column chromatography to yield $15 \mathrm{mg}$ of metabolite $9\left(R_{f} 0.25, n\right.$-hexane/EtOAc, 3:2). $R$. stolonifer fermentation extract was subjected to normal-phase MPLC to collect fractions rich in metabolites 5-8. The least polar fraction was subjected to preparative TLC on silica gel to afford compound 5 (5 mg, $R_{f} 0.28, \mathrm{CHCl}_{3} / \mathrm{MeOH}$, 3:2). Subsequent MPLC of other fractions afforded metabolites 6 (7 
mg, $\left.R_{f} 0.22, \mathrm{CHCl}_{3} / \mathrm{MeOH}, 3: 2\right), 7$ (9 mg, $\left.R_{f} 0.21, \mathrm{CHCl}_{3} / \mathrm{MeOH}, 3: 2\right)$, and $\mathbf{8}\left(3 \mathrm{mg}, R_{f} 0.18, \mathrm{CHCl}_{3} / \mathrm{MeOH}, 3: 2\right)$.

Wound-Healing Assays. Murine melanoma cells (B16B15b) were maintained in DMEM F12 + 5\% FBS. The method used to detect migration by wound-healing assay was previously described. ${ }^{19-21}$ Briefly, the cells were allowed to grow to $100 \%$ confluency in 24-well plates. Once the monolayer developed, a wound was made with a 100 $\mu \mathrm{L}$ pipet tip. The detached cells were then washed three times with serum-free medium (SFM). The cells were treated with 1,10 , or 100 $\mu \mathrm{M}$ solutions of each of the tested cembranoids in Dulbecco's modified Eagle's medium (DMEM/F12) + 5\% FBS + penicillin/streptomycin $(1 \%)$ for a period of $16 \mathrm{~h}$. Wound width was measured immediately before $\left(W_{0}\right)$ and after the $16 \mathrm{~h}\left(W_{16}\right)$ incubation $\left(\Delta W=W_{0}-W_{16}\right)$ (Figure 1). Figure 2 represents wound closure values for different concentrations of compounds $(\mathbf{2}, \mathbf{3}, \mathbf{5}-\mathbf{9})$ in millimeters, relative to the control (time 0). All experiments were conducted independently in triplicate.

Cell Proliferation Assays by Fluorescence-Based Analysis. B16B15b cells were maintained as mentioned above and were plated in 24-well tissue culture plates at 2500 cells/well. This was followed by an incubation period of $24 \mathrm{~h}$ at $37{ }^{\circ} \mathrm{C}$ to allow for cell attachment. On the day of the treatment, medium was replaced with fresh growth medium containing 1,10 , or $100 \mu \mathrm{M}$ cembranoid derivatives $+1 \%$ penicillin and streptomycin. Cells were then incubated for $24 \mathrm{~h}$, after which the medium was replaced with fresh growth medium containing $10 \%$ Alamar Blue (BioSource International, Camarillo, CA). This safe, nontoxic dye is used to monitor and assess the innate metabolic activity of the cells. ${ }^{22}$ Cells were then incubated for $4 \mathrm{~h}$, and fluorescence was detected using a CytoFluor multiwell-plate reader (CytoFluor 4000, Applied Biosystems, Foster City, CA). ${ }^{22}$ Cell numbers were calculated using a standard curve. All experiments were conducted independently and in triplicate.

Analytical Data. 1,15 $\beta$-Epoxy-2-epi-16-deoxysarcophine (5): colorless oil; $[\alpha]_{\mathrm{D}}{ }^{25}-10.2(c 0.22, \mathrm{MeOH})$; UV $\lambda_{\max }(\log \epsilon)(\mathrm{MeOH}) 204$ (3.7); IR $v_{\max }$ (neat) $3017,2931,2857,1662,1516,1449,1385,1215$, 1033, $755 \mathrm{~cm}^{-1}$; ${ }^{1} \mathrm{H}$ and ${ }^{13} \mathrm{C}$ NMR, see Table 1; HRESITOF $\mathrm{m} / \mathrm{z}$ $341.2093(\mathrm{M}+\mathrm{Na})^{+}$(calcd for $\left.\mathrm{C}_{20} \mathrm{H}_{30} \mathrm{O}_{3} \mathrm{Na}, 341.2093\right)$.

$9 \alpha$-Hydroxy-2-epi-16-deoxysarcophine (6): colorless oil; $[\alpha]_{\mathrm{D}}^{25}$ +52.0 ( $c$ 0.05, MeOH); UV $\lambda_{\max }(\log \epsilon)(\mathrm{MeOH}) 204$ (4.4); IR $v_{\max }$ (neat) $3018,2930,2858,2399,1521,1436,1215,1032,771,669 \mathrm{~cm}^{-1}$; ${ }^{1} \mathrm{H}$ and ${ }^{13} \mathrm{C}$ NMR, see Table 1; HRESITOF $\mathrm{m} / z, 341.2089(\mathrm{M}+\mathrm{Na})^{+}$ (calcd for $\mathrm{C}_{20} \mathrm{H}_{30} \mathrm{O}_{3} \mathrm{Na}, 341.2093$ ).

10 $\beta$-Hydroxy-2-epi-16-deoxysarcophine (7): colorless oil; $[\alpha]_{\mathrm{D}}{ }^{25}$ -62.1 ( c 0.19, MeOH); UV $\lambda_{\max }(\log \epsilon)(\mathrm{MeOH}) 204$ (4.7); IR $v_{\max }$ (neat) $3683,3019,2929,2857,2400,1521,1425,1385,1215,1032$, 929, 755, $669 \mathrm{~cm}^{-1} ;{ }^{1} \mathrm{H}$ and ${ }^{13} \mathrm{C}$ NMR, see Table 1; HRESITOF $\mathrm{m} / \mathrm{z}$ $341.2090(\mathrm{M}+\mathrm{Na})^{+}\left(\right.$calcd for $\left.\mathrm{C}_{20} \mathrm{H}_{30} \mathrm{O}_{3} \mathrm{Na}, 341.2093\right)$.

14/-Hydroxy-2-epi-16-deoxysarcophine $(9)$ : colorless oil; $[\alpha]_{\mathrm{D}}^{25}$ +69.3 ( c 0.08, MeOH); UV $\lambda_{\max }(\log \epsilon)(\mathrm{MeOH}) 204$ (4.2); IR $v_{\max }$ (neat) 3019, 2935, 2865, 2399, 1535, 1433, 1394, 1215, 928, 759, 669 $\mathrm{cm}^{-1}$; ${ }^{1} \mathrm{H}$ and ${ }^{13} \mathrm{C}$ NMR, see Table 2; HRESITOF $\mathrm{m} / \mathrm{z} 341.2079(\mathrm{M}+$ $\mathrm{Na})^{+}$(calcd for $\mathrm{C}_{20} \mathrm{H}_{30} \mathrm{O}_{3} \mathrm{Na}, 341.2093$ ).

Acknowledgment. R. A. Hill, ULM, is acknowledged for his valuable suggestions and discussions. N. Sinnapah-Kang and M. Roy,
LSU, are acknowleged for their valuable dicussions and assistance in cytotoxicity assays. This publication was made possible by NIH Grant Number P20RR16456 from the BRIN Program of the National Center for Research Resources. Its contents are solely the responsibility of the authors and do not necessarily represent the official views of NIH. Research described in this article was supported in part by Philip Morris USA Inc. and Philip Morris International.

\section{References and Notes}

(1) Tursch, B.; Braekman, J. C.; Daloze, D.; Kaisin, M. In Marine Natural Products; Scheuer, P. J., Ed.; Academic Press: New York, 1978; Vol 2.

(2) Coll, J. C.; Bowden, B. F.; Tapiolas, D. M.; Willis, R. H.; Djura, P.; Streamer, M.; Trott, L. Tetrahedron 1985, 41, 1085-1092.

(3) Pham, N. B.; Butler, M. S.; Quinn, R. J. J. Nat. Prod. 2002, 65, $1147-1150$

(4) Anjaneyulu, R.; Rao, G. V. J. Indian Chem. Soc. 1997, 74, 272278.

(5) Fujiki, H.; Suganuma, M.; Takagi, K.; Nishiwaki, S.; Yoshizawa, S.; Okabe, S.; Yatsunami, J.; Frenke, K.; Troll, W.; Marshall, J. A.; Tius, M. A. Phenolic Compounds in Food and Their Effects on Health. II. Antioxid. Cancer Prev. 1992, 380-387.

(6) El Sayed, K. A.; Hamann, M. T.; Waddling, C. A.; Jensen, C.; Lee, S. K.; Dunstan, C. A.; Pezzuto, J. M. J. Org. Chem. 1998, 63, 74497455 .

(7) Katsuyama, I.; Fahmy, H.; Zjawiony, J. K.; Khalifa, S. I.; Kilada, R. W.; Konoshima, T.; Takasaki, M.; Tokuda, H. J. Nat. Prod. 2002, $65,1809-1814$.

(8) Sawant, S. S.; Sylvester, P. W.; Avery, M. A.; Desai, P.; Youssef, D. T. A.; El Sayed, K. A. J. Nat. Prod. 2004, 67, 2017-2023.

(9) Thayer, A. M. Chem. Eng. News 2001, 79 (21), 27-34.

(10) Shanahan-Pendergast, E. International Patent WO 02053138. CAN $137: 88442$

(11) Bernstein, J.; Shmeuli, U.; Zadock, E.; Kashman, Y.; Ne'eman, I. Tetrahedron 1974, 30, 2817-2824.

(12) Czarkie, D.; Carmely, S.; Groweiss, A.; Kashman, Y. Tetrahedron 1985, 41, 1049-1056.

(13) Bowden, B. F.; Coll, J. C.; Heaton, A.; König, G. J. Nat. Prod. 1987, 50 (4), 650-659.

(14) Frincke, J. M.; McIntyre, D. E.; Faulkner, D. J. Tetrahedron 1980, $21,735-738$.

(15) Kashman, Y.; Bodner, M.; Loya, Y.; Benayahu, Y. Isr. J. Chem. 1977, 16, 1-3.

(16) Gross, H.; Wright, A. D.; Beil, W.; Konig, G. M. Org. Biomol. Chem. 2004, 2, 1133-1138.

(17) Yamada, K.; Ryu, K.; Miyamoto, T.; Higuchi, R. J. Nat. Prod. 1997, $60,798-801$.

(18) Li, G.; Zhang, Y.; Deng, Z.; Ofwegen, L. V.; Proksch, P.; Lin, W. J. Nat. Prod. 2005, 68, 649-652.

(19) Tang, S.; Morgan, K. G.; Parker, C.; Ware, J. A. J. Biol. Chem. 1997, $272,28704-28711$.

(20) Marchetti, D.; Menter, D. D.; Jin, L.; Nakajima, M.; Nicolson, G. L. Int. J. Cancer 1993, 55, 692-699.

(21) Murry, B. P.; Blust, B. E.; Singh, A.; Foster, T. P.; Marchetti, D. J. Cell. Biochem. 2006, 97, 217-225.

(22) Sinnappah-Kang, N. D.; Kaiser, A. J.; Blust, B. E.; Mrak, R. E.; Marchetti, D. Int. J. Oncol. 2005, 27, 617-626.

NP050527V 